\title{
Cytogenetic analysis of reconstituted one-cell mouse embryos derived from nuclear transfer of fetal male germ cells
}

\author{
Y. Tsunoda ${ }^{1}$, Y. Kato ${ }^{1}$ and G. T. O'Neill ${ }^{2}$ \\ ${ }^{1}$ Laboratory of Animal Reproduction, College of Agriculture, Kinki University, Nara, Japan; and \\ ${ }^{2}$ Institute of Animal Physiology and Genetics Research, Edinburgh Research Station,
} Roslin EH25 9PS, UK

\begin{abstract}
Summary. Micromanipulation techniques were used to produce reconstituted one-cell mouse embryos after the fusion of fetal male germ cells 15.5 day post coitum with enucleated secondary oocytes. At this stage of development, male fetal germ cells are arrested at Gl of mitotic interphase. Two distinct populations of germ cells, differing in size and ploidy, were isolated from the genital ridge of a mid-term fetus. Oocytes that had received male germ cells from the population of smaller (mononuclear) germ cells developed as diploid one-cell reconstituted embryos. When the same procedures were used to produce reconstituted one-cell embryos using male fetal germ cells from a population of larger (multinucleate) cells, they exhibited ploidy of either $4 \mathrm{x}, 6 \mathrm{x}$ or $8 \mathrm{x}$ at metaphase of the first cell division. Although most reconstituted embryos ( 90 and $96 \%$ ) developed to the two-cell stage, the proportion of embryos receiving small germ cells developed to blastocysts was much higher $(62 \%)$ than that receiving large germ cells $(4 \%)$. These studies indicate that not all fetal germ cells are diploid before the onset of meiosis and have identified procedures to produce reconstituted embryos from fetal germ cells that do not carry genome or chromosome anomalies.
\end{abstract}

Key'words: chromosome constitution; nuclear transfer; germ cell; mouse

\section{Introduction}

Before the onset of meiosis, mammalian germ cells, should possess a diploid constitution to ensure the development of haploid gametes. De Felici \& McLaren (1983) observed that some germ cells isolated from female embryos at 13.5-15.5 days post coitum were multinucleate. Dissel-Emiliani et al. (1989) also isolated populations of bi- and trinucleate male germ cells from the gonads of rat fetuses using velocity sedimentation techniques. Subsequent development of male and female germ cells differs at this stage of embryogenesis. At 14.5 days post coitum germ cells in the female gonad initiate meiosis and arrest at the dictyate stage of meiotic prophase. In contrast, male germ cells cease mitotic proliferation at this stage of development and arrest at the Gl stage (McLaren, 1984). However, there are no studies of the chromosome constitution of male or female germ cells at these stages of development, owing to the difficulty of performing an in vitro culture of germ cells, particularly in males (De Felici \& McLaren, 1983; McLaren \& Buehr, 1990).

The production of reconstituted salamander embryos by the fusion of germ cells with enucleated oocytes resulted in the development of live fertile offspring (LeSimple et al., 1987). The transfer of 14-5-15.5-day-old male fetal germ cells to enucleated ovulated oocytes may cause limited nuclear remodelling with preimplantation development after ethanol-induced oocyte activation (Tsunoda et al., 1989). Nuclear remodelling is the result of modifications to the organization of the introduced nucleus by ooplasmic factors that are active during the completion of the second meiotic 
division (Czolowska et al., 1986; Szollosi, 1988). Development to the blastocyst stage was observed when male germ cells isolated at 14.5-15.5 days post coitum were used as donor nuclei fused with enucleated secondary oocytes. However, the chromosome constitution of these embryos was not examined and no live births were noted. Male fetal germ cells from an embryo at 12.5-14.0 days post coitum were found to be less efficient for promoting preimplantation development of reconstituted embryos. Germ cells at 12.5-14.0 days post coitum are mitotically active and the introduction of nuclei at stages of the cell cycle, such as $\mathbf{S}$ and $\mathbf{M}$ phases, may be unfavourable for nuclear remodelling and may have adversely influenced subsequent embryonic development.

This study was conducted to examine the chromosome constitution of fetal germ cells used to produce reconstituted one-cell embryos by standard nuclear transfer and cytogenetic techniques and to determine the relationship of the data obtained to the previously observed ability of male germ cells to contribute to early embryonic development.

\section{Materials and Methods}

\section{Isolation of germ cells and oocytes}

Male germ cells were recovered from fetuses from natural matings between albino CD-1 mice 15.5 days post coitum. The germ cells were recovered from the genital ridges of male fetuses according to the method of De Felici \& McLaren (1983) and Hogan et al. (1986). The cells were viable as shown by negative staining for Trypan blue, for $5 \mathrm{~h}$ after isolation (Kato et al., 1990). They were maintained in PBI (Whittingham \& Wales, 1969) supplemented with $10 \%$ fetal calf serum. Ovulated oocytes were obtained from $(\mathrm{C} 57 \mathrm{BL} \times \mathrm{CBA}) \mathrm{F}_{1}$ female mice $15-17 \mathrm{~h}$ after intraperitoneal injection of 5 iu of human chorionic gonadotrophin ( $\mathrm{hCG}$ ) to induce superovulation. Cumulus masses were washed in an M2 embryo culture medium (Fulton \& Whittingham, 1978) supplemented with 300 iu of hyaluronidase to remove adhering cumulus cells from the oocytes. The oocytes were washed in M2 before enucleation and used as recipient oocytes.

\section{Nuclear transfer}

The zonae pellucidae of the ovulated oocytes were cut along 10-20\% of their circumference using a fine glass needle. This assisted subsequent removal of second metaphase apparatus and later transfer of donor nuclei (Tsunoda et al., 1986). The ovulated oocytes were incubated with Hoechst $33342\left(2 \mu \mathrm{g} \mathrm{ml}{ }^{-1}\right)$ for $5 \mathrm{~min}$ and incubated with M2 medium containing cytochalasin B and colcemid for $15 \mathrm{~min}$. The second metaphase chromosomes were removed with an enucleation pipette by using a micromanipulator under a fluorescence microscope within $15 \mathrm{~s}$ (Tsunoda et al., 1988). The first polar body was also removed from the oocytes.

Large (multinucleate) and small (mononucleate) germ cells (Fig. 1) were transferred with a small volume of inactivated Sendai virus (2700 haemagglutinating units) into the perivitelline space of enucleated oocytes. Oocyte activation was induced within $15 \mathrm{~min}$ of germ cell transfer by exposure to $7 \%$ ethanol for $7 \mathrm{~min}$ at room temperature (Kaufman, 1982; Cuthbertson, 1983). The oocytes were washed in M2 and maintained in MI6 embryo culture medium (Whittingham, 1971) in $5 \% \mathrm{CO}_{2}$ at $37^{\circ} \mathrm{C}$. At 5-6 h after exposure to ethanol, activated oocytes showed donor germ cell nuclei with pronuclear-like swelling. The reconstituted embryos were transferred to M16 supplemented with $1 \mathrm{\mu g}^{-1}$ colcemid $\mathrm{ml}^{-1}$ to arrest development at metaphase of the first cleavage division. Air-dried chromosome spreads of the reconstituted one-cell embryos, non-activated oocytes and oocytes in which cell fusion had failed to occur were prepared early on the morning of the following day as described by Tarkowski (1966) and O'Neill et al. (1990). Developmental ability was examined by culturing reconstituted embryos to blastocysts for 5 days in M 16 and transferring the reconstituted blastocysts to the oviducts of day 1 pseudopregnant CD-1 strain females (Bronson \& McLaren, 1970). Reconstituted blastocysts were transferred to oviducts because it has been observed (Tsunoda \& McLaren, 1983) that micromanipulated half embryos had a better chance of developing to young when they were transferred into oviducts of day 1 pseudopregnant recipients rather than to uteri of day 3 recipients $(27 \%$ versus $17 \%$ ). The recipients were killed on day 9.5 for examination of implantation sites. The data were analysed by $\chi^{2}$ analysis.

\section{Results}

Enucleated oocytes, 268, received a small male fetal germ cell (Table 1). After activation and in vitro culture for $5-6 \mathrm{~h}, 25$ oocytes $(9 \cdot 3 \%)$ exhibited a pronuclear-like swelling of the transferred nucleus. There was a significantly higher (18/48: 38\% $P<0.01)$ incidence of fusion and pronuclear-like 


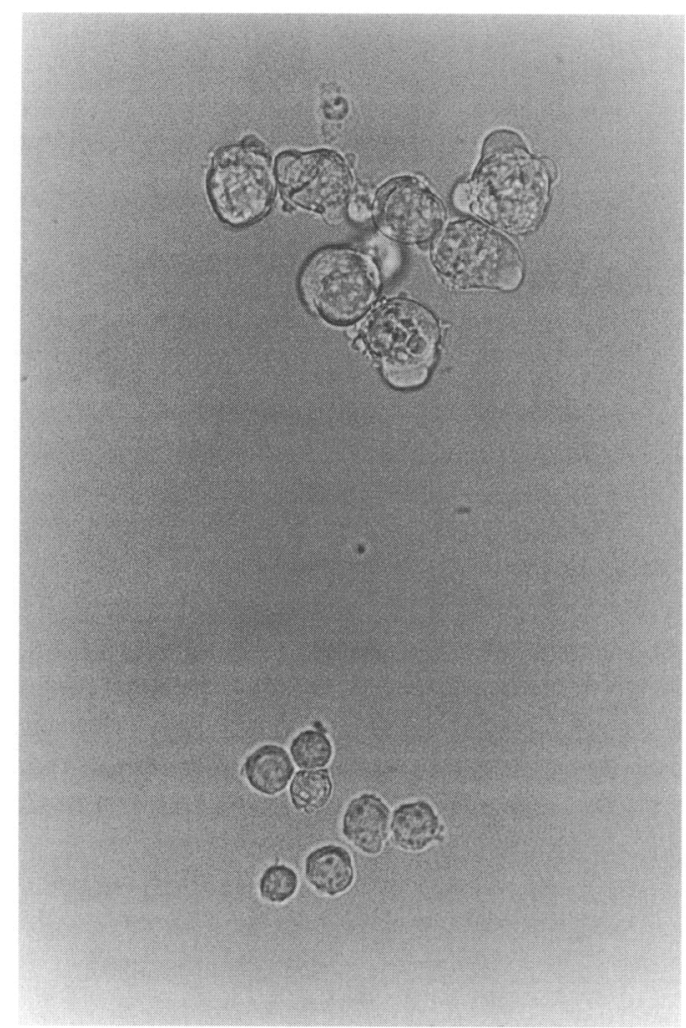

Fig. 1. Germ cells from gonads of male fetuses 15.5 days post-coitum. Large (multinucleate) and small (diploid) germ cells are present.

swelling when larger multinucleate germ cells were situated next to the oocyte membrane (Table 1). Air-dried, Giemsa-stained preparations of oocytes in which germ-cell fusion failed to occur revealed a small non-activated densely staining nucleus lying outside the ooplasm. These non-incorporated fetal germ cells had remained at interphase.

Table 1. Chromosome constitution of one-cell reconstituted embryos that result from the fusion of germ cells from male mouse fetuses $15 \cdot 5$ days post coitum and ovulated oocytes

\begin{tabular}{|c|c|c|c|c|c|c|c|c|c|}
\hline \multirow{2}{*}{$\begin{array}{l}\text { Class of } \\
\text { germ cell }\end{array}$} & \multirow{2}{*}{$\begin{array}{c}\text { Number of } \\
\text { activated oocytes } \\
\text { total }(\%)\end{array}$} & \multicolumn{2}{|c|}{ Number of } & \multicolumn{5}{|c|}{ Ploidy } & \multirow{2}{*}{$\begin{array}{c}\text { Not } \\
\text { analysedt }\end{array}$} \\
\hline & & & & $2 \mathrm{x}$ & $2 x+2 x$ & $4 x$ & $6 x$ & $8 x$ & \\
\hline $\begin{array}{l}\text { Multinucleate } \\
\text { (large) }\end{array}$ & $\begin{array}{l}18 / 48 \\
(37 \cdot 5)\end{array}$ & 10 & $8^{*}$ & $\begin{array}{l}0 \\
0\end{array}$ & $\begin{array}{l}0 \\
4\end{array}$ & $\begin{array}{l}5 \\
1\end{array}$ & $\begin{array}{l}2 \\
1\end{array}$ & $\begin{array}{l}1 \\
0\end{array}$ & $\begin{array}{l}2 \\
2\end{array}$ \\
\hline $\begin{array}{l}\text { Mononucleate } \\
\text { (smali) }\end{array}$ & $\begin{array}{c}25 / 268 \\
(9 \cdot 3)\end{array}$ & 24 & 1 & $\begin{array}{c}16+ \\
0\end{array}$ & $\begin{array}{l}0 \\
0\end{array}$ & $\begin{array}{l}0 \\
0\end{array}$ & $\begin{array}{l}0 \\
0\end{array}$ & $\begin{array}{l}0 \\
0\end{array}$ & $\begin{array}{l}8 \\
1\end{array}$ \\
\hline
\end{tabular}

\footnotetext{
* One embryo exhibited three pronuclei but the chromosome content could not be analysed; three embryos exhibited a hypodiploid chromosome number. PN: pronucleus.
}

Most (10/18) reconstituted one-cell embryos that developed after transfer of large multinucleate germ cells showed a single pronucleus. However, in many case, two $(7 / 18)$ or three $(1 / 18)$ pronuclei were seen. Only one reconstituted one-cell embryo that developed after fusion between a small 
germ cell and an enucleated oocyte showed two nuclei. The number of chromosomes in this preparation could not be determined exactly, but it was not polyploid. This example may have exhibited micronuclei. The other embryos exhibited a single pronucleus.

Cytogenetic analysis of $14(78 \%)$ oocytes reconstituted with a large germ cell at the metaphase of the first cleavage of mitosis indicated two sets of $2 \mathrm{x}, 4 \mathrm{x}, 6 \mathrm{x}$ or $8 \mathrm{x}(2 n=80,80,120$ or 160 , respectively) polyploid constitution, as $4 n, 6 n$ or $8 n$ (Fig. $2 \mathrm{a}-\mathrm{c}$ ). In four cases, accurate chromosome count was not possible but the diploid number $2 n=40$ was always exceeded. Analysis of $16(65 \%)$ oocytes reconstituted with small germ cells revealed that all were diploid (Fig. 2 d). In this group, most of the chromosome spreads could be analysed and three were hypodiploid, showing $2 n=35$, 38 or 39 chromosomes, respectively.

The number of activated oocytes that had received a large germ cell was again found to exceed significantly that of oocytes that had received a small germ cell (Table 2). Most of the reconstituted oocytes with large (96\%) and small $(90 \%)$ germ cells developed to the two-cell stage, but many that had received a small germ cell $(62 \%)$ developed into blastocysts $\left(\chi^{2}=7 \cdot 1, P=0.05-0.02\right)$, in contrast to those that had received a large germ cell $(4 \%)$. Five blastocysts that developed from reconstituted oocytes that had a small germ cell were transferred to two recipients. Each had two implantation sites $(80 \%)$, but no fetuses.

\section{Discussion}

This study analysed the chromosome constitution of male fetuses germ cells 15.5 days post coitum and, as also noted in previous cytological studies, diploid and polyploid germ cells were found to co-exist in the fetal gonad. Most polyploid germ cells that were induced to progress to metaphase after activation in the enucleated oocytes were observed to be tetraploid and hexaploid. One of the reconstituted embryos was octaploid. Although the relative proportions of these types of cell were not examined in this study, their proportionate incidence in the fetal gonad 15.5 days post coitum may relate closely to their observed frequency in the reconstituted embryos. In this study, only one reconstituted embryo with a pronuclear number greater than three was observed. This indicates that embryos with a $6 n$ or $8 n$ constitution may have polyploid pronuclei. The multinucleate germ cells may arise by cell fusion, rather than the absence of cytokinesis. Cytoplasmic bridges have been observed between germ cells in gonads of fetuses (Dissel-Emiliani et al., 1989), and these may later result in the formation of multinucleate cells in which subsequent mitosis fails to occur. The mechanism of multinucleate germ cell formation and the subsequent fate of this class of cell has yet to be identified. A large proportion of male germ cells degenerate at subsequent periods of gametogenesis (Byskov, 1982) and these cells may represent a significant proportion of the cells that are predisposed to atresia during both male and female gametogenesis owing to their apparent unsuitability for subsequent meiotic maturation.

The binucleate constitution of tetraploid one-cell embryos was observed to be retained in four of the reconstituted one-cell embryos as the metaphase chromosomes were clearly arranged as two distinct diploid plates $(40+40)$. The remaining embryos did not exhibit this feature as the chromosome spreading technique would disrupt the metaphase plates of the polyploid cells. Three of the reconstituted embryos that developed after transfer of a small mononucleate germ cell were found to exhibit a hypodiploid number. This may have been the result of the mechanical loss of chromosomes incurred during embryo fixation. A second factor that may have contributed to the induction of chromosome loss was the dispersal of chromosomes from the germ cell nucleus if cell fusion was not in synchrony with the activation of the recipient oocyte. Sendai virus assisted fusion between the oocyte and the smaller diploid germ cells was observed less frequently because of the smaller area of apposition between their membranes. The nuclei of germ cells fused with enucleated non-activated oocytes exhibit premature chromosome condensation (Tsunoda, unpublished; see Czolowska et al., 1986) but can subsequently develop along the pronuclear-like pathway after 
(a)

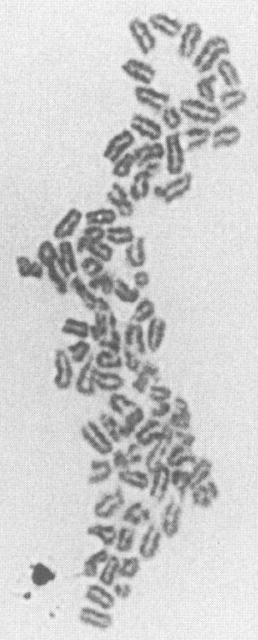

(c)

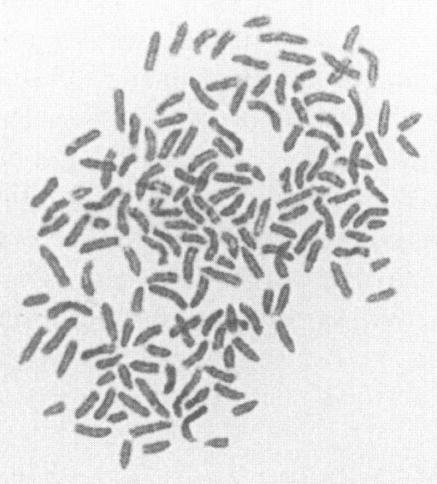

4 (b)

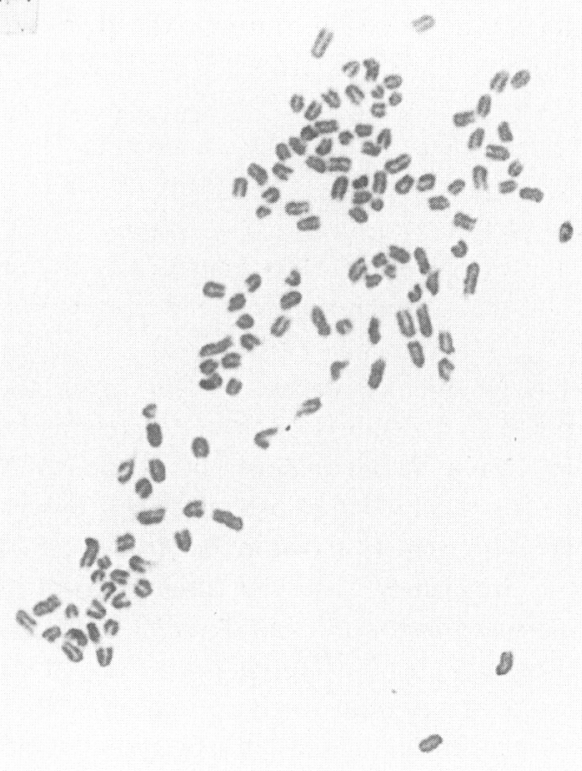

(d)

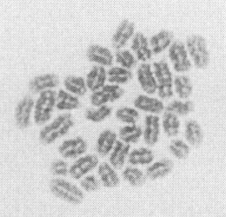

Fig. 2. Air dried chromosome spreads from reconstituted one-cell embryos at metaphase of mitosis of the first cleavage that exhibit either (a) 80, (b) 120 , (c) 160 or (d) 40 chromosomes. All preparations were stained with $3 \%$ Giemsa stain at pH $6 \cdot 8$. 
Table 2. In vitro development of reconstituted embryos receiving germ cells of male mouse $15 \cdot 5$ days post coitum

\begin{tabular}{lccccc}
\hline Class of & $\begin{array}{c}\text { Number of } \\
\text { germ cell } \\
\text { octivated } \\
\text { total }(\%)\end{array}$ & \multicolumn{3}{c}{$\begin{array}{c}\text { In vitro development of reconstituted } \\
\text { eggs activated }(\%)\end{array}$} \\
\cline { 2 - 6 } & $\begin{array}{c}\text { 2-cell } \\
\text { 4-cell }\end{array}$ & 8-cell & Blastocyst \\
\hline Large & $23 / 101(23)$ & $22(96)$ & $10(43)$ & $6(26)$ & $1(4)$ \\
Small & $21 / 191(11)$ & $19(90)$ & $16(76)$ & $15(71)$ & $13(62)$ \\
\hline
\end{tabular}

parthenogenetic activation (Tsunoda et al., 1989). A delay between the time of fusion and activation in a small proportion of reconstituted oocytes may have induced this phenomenon in conjunction with the dispersal of chromatin before nuclear swelling and remodelling.

We reported (Tsunoda et al., 1989) previously that some of the reconstituted one-cell embryos had the potential to develop in vitro to the blastocyst stage. No note was made of germ cell size, but the previously observed rates of fusion and activation would indicate that a proportion of reconstituted embryos was derived from the larger multinucleate class of fetal germ cells. The present study clearly demonstrates that the development of reconstituted diploid one-cell embryos to blastocysts is quite high compared with that of reconstituted eggs of polyploid constitution. However, transfer of these blastocysts did not result in live fetuses, as also noted in our previous study (Tsunoda et al., 1989). Although we did not transfer control embryos, Bronson \& McLaren (1970) obtained fetuses on day 9.5 of pregnancy in $67 \%$ of cases after transfer of morulae and blastocysts to oviducts of day 1 pseudopregnant recipients. Tokunaga et al. (1985) obtained live young in $27 \%$ of cases after transfer of blastocysts developed from pronuclear-exchanged eggs. Live young have been produced when the germ cells of the salamander are used as donor nuclei (LeSimple et al., 1987). Mammalian germ cells exhibit DNA hypomethylation in relation to other somatic tissues of the early embryo (Monk, 1990). These epigenetic modifications may represent necessary changes that accompany alterations to genomic imprinting in the germline and the reestablishment of germ cell pluripotency. A high proportion of parthenogenetic or gynogenetic mouse eggs develop to blastocysts $(80-90 \%)$ but less than $20 \%$ of androgenetic eggs develop to blastocysts (Norris et al., 1990). However, 62\% of reconstituted eggs with male small germ cells developed to blastocysts (in the present study), but none of the eggs receiving female germ cells developed to blastocysts (Tsunoda, unpublished). We cannot explain this, but it would be interesting to compare the post-implantation development of gynogenetic eggs and eggs receiving male germ cells. Since so few blastocysts generated by nuclear transplantation were transferred in the present study, a large scale study of embryo transfer data is necessary to determine why reconstituted eggs receiving germ cells of male fetuses fail to develop.

Y. Tsunoda and Y. Kato thank M. Yoshizawa, Faculty of Agriculture, University of Utsunomiya for guidance with cytogenetic techniques. Y. Tsunoda and Y. Kato were supported with grants from the Japanese Ministry of Science and Technology (Developmental Biotechnology), Ministry of Education, Science and Culture, Bioscience Laboratories (Yamagata), Human Science Foundation, Inamori Foundation and Kinki University. G. T. O'Neill is funded by the AFRC (UK) and the OECD Co-operative Research Project on Biological Resource Management.

\section{References}

Bronson, R. \& McLaren, A. (1970) Transfer to the mouse oviduct of eggs with and without the zona pellucida. Journal of Reproduction and Fertility 22, 129-137.

Byskov, A.G. (1982) Primordial germ cells and regulation of meiosis. In Reproduction in Mammals, Vol. 1, pp. 1-16. Eds C. R. Austin \& R. V. Short. Cambridge University Press, London.

Cuthbertson, K.S.R. (1983) Parthenogenetic activation of mouse oocytes in vitro with ethanol and benzyl alcohol. Journal of Experimental Zoology 226, 311-314. 
Czolowska, R., Modlinski, J. \& Tarkowski, A.K. (1984) Behaviour of thymocyte nuclei in non-activated and activated oocytes. Journal of Cell Science 69, 19-34.

Czolowska, R., Waksmundzka, M., Kubiak, J.Z. \& Tarkowski, A.K. (1986) Chromosome condensation activity in ovulated metaphase II mouse oocytes assayed by fusion with interphase blastomeres. Journal of Cell Science 84, 129-138.

De Felici, M. \& McLaren, A. (1983) In vitro culture of mouse primordial germ cells. Experimental Cell Research 144, 417-427.

Dissel-Emmiliani van, F.M.F., Rooiji de, D.G. \& Meistrich, M.L. (1989) Isolation of rat gonocytes by velocity sedimentation at unit gravity. Journal of Reproduction and Fertility 86, 759-766.

Fulton, B.P. \& Whittingham, D.G. (1978) Activation of mammalian oocytes by intracellular injection of calcium. Nature 273, 149-151.

Hogan, B., Constantini, F. \& Lacy, E. (1986) In Manipulating the Mouse Embryo, pp. 127-130. Cold Spring Harbor Laboratory, New York.

Kato, Y., Sugiyama, K. \& Tsunoda, Y. (1990) Studies on the isolation, identification and viability of primordial germ cells in the mouse. Japanese Journal of Animal Reproduction 36, 235-239.

Kaufman, M.H. (1982) The chromosome complement of single-pronuclear haploid mouse embryos following activation by ethanol treatment. Journal of Embryology and Experimental Morphology 71, 139-154.

LeSimple, M., Dournon, C., LaBrousse, M. \& Houillon, C.H. (1987) Production of fertile salamanders by transfer of germ cell nuclei into eggs. Development $100,471-477$.

McLaren, A. (1984) Meiosis and differentiation of mouse germ cells. In Controlling Events in Meiosis, pp. 7-23. Ed. H. G. Dickinson. Society for Experimental Biology Symposium 38, Cambridge University Press, Cambridge.

McLaren, A. \& Buehr, M. (1990) Development of mouse germ cells in cultures of fetal gonads. Cell Differentiation and Development 31, 185-195.

Monk, M. (1990) Changes in DNA methylation during mouse embryonic development in relation to $\mathrm{X}$ chromosome activity and imprinting. Philosophical
Transactions of the Royal Society of London, Series B 326, 299-312.

Norris, M.L., Barton, S.C. \& Surani, M.A.H. (1990) The differential role of parental genomes in mammalian development. In Oxford Review's of Reproductive Biology, pp. 225-244. Ed. S. R. Milligan. Oxford University Press, Oxford.

O'Neill, G.T., Speirs, S. \& Kaufman, M.H. (1990) Sex-chromosome constitution of postimplantation tetraploid mouse embryos. Cytogenetics and Cell Genetics 53, 191-195.

Szollosi, D., Czolowska, R., Szollosi, M. \& Tarkowski, A.K. (1988) Remodelling of mouse thymocyte nuclei depends on the time of their transfer into activated, homologous oocytes. Journat of Cell Science 91, $603-613$.

Tarkowski, A.K. (1966) An air-drying method for chromosome preparations from mouse eggs. Cytogenetics $\mathbf{5}$, $394-400$.

Tokunaga, T., Tsunoda, Y. \& Sugie, T. (1985) Viability of gynogenetic mouse embryos. Japanese Journal of Animal Reproduction 31, 181-185.

Tsunoda, Y. \& McLaren, A. (1983) Effect of various procedures on the viability of mouse embryos containing half the normal number of blastomeres. Journal of Reproduction and Fertility 69, 315-322.

Tsunoda, Y., Yasui, T., Nakamura, K. \& Sugie, T. (1986) Effect of cutting the zona pellucida on pronuclear transplantation in the mouse. Journal of Experimental Zoology 240, 119-125.

Tsunoda, Y., Shioda, Y., Onodera, M., Nakamura, K. \& Uchida, T. (1988) Differential sensitivity of mouse pronuclei and zygote cytoplasm to Hoechst staining and ultraviolet irradiation. Journal of Reproduction and Fertility 82, 173-178.

Tsunoda, Y., Tokunaga, T., Imai, H. \& Uchida, T. (1989) Nuclear transplantation of male primordial germ cells in the mouse. Development 107, 407-411.

Whittingham, D.G. (197I) Culture of mouse ova. Journal of Reproduction and Fertility Supplement 14, 7-21.

Whittingham, D.G. \& Wales, R.G. (1969) Storage of 2cell embryos in vitro. Australian Journal of Biological Sciences 22, 1065-1068.

Received 19 August 1991 